Кірпічніков Ю. А., к.т.н. (ORCID: 0000-0001-6893-3569);

Андрощук О. В., к.психол.н. (ORCID: 0000-0002-1032-7459);

Головченко О. В.

(ORCID: 0000-0003-4444-0764);

Петрушен М. В.

(ORCID: 0000-0002-7448-2765)

Центр воєнно-стратегічних досліджень Національного університету оборони України імені Івана Черняховського, Київ

\title{
Визначення технологічних рішень щодо створення Сдиної інформаційної системи управління оборонними ресурсами
}

Резюме. У Міністерстві оборони України здійснюється створення Сдиної інформаційної системи управління оборонними ресурсами. Статтю присвячено проблемі визначення технологічних рішень щодо побудови інформаційної інфраструктури, що є основою системи такого рівня.

Ключові слова: управління оборонними ресурсами; інформаційна інфраструктура; система інтеграції даних; інтеграційна платформа; сервісна шина обміну даними.

Постановка проблеми. Активізація євроатлантичної інтеграції України та пов'язане 3 цим реформування сфери безпеки i оборони за європейськими стандартами належать до найважливіших пріоритетів як зовнішньої, так і внутрішньої політики України. Підтримання цих процесів на належному рівні неможливе без управління оборонними ресурсами, що має враховувати здатність національної економіки зберігати та оновлювати оборонний потенціал держави.

У Міністерстві оборони (МО) України та Генеральному штабі (ГШ) Збройних Сил (3С) України здійснюються певні заходи щодо підвищення ефективності управління оборонними ресурсами. Проте підвищити якість управлінської діяльності неможливо без поширення i поглиблення процесу інформатизації, використання сучасних інформаційних технологій (IT), що дасть змогу не тільки накопичувати інформацію щодо оборонних ресурсів, але й здійснювати ефективне управління ними на основі всебічного аналізу, встановлення причиннонаслідкових зв’язків між процесами.

В умовах високої багатоаспектності та складності задач управління оборонними ресурсами критично важливим стає забезпечення розроблення, впровадження i використання IT, починаючи 3 постановки завдань, визначення джерел отримання інформації, застосування математичних засобів інформаційно-аналітичної підтримки до створення цілісної інформаційної інфраструктури МО України та ГШ ЗС України.

Ступінь розробленості проблеми. Протягом тривалого часу у ЗС України створювались та розвивались окремі автоматизовані, інформаційні, інформаційноаналітичні та інші програмні системи, які не зв'язані між собою. Територіально розподілена інформаційна інфраструктура оборонного відомства країни на сьогодні характеризується відокремленістю та ізольованістю їі складових $[1,2]$.

Розуміння необхідності об'єднання усіх наявних інформаційних систем (IC) MO України та 3С України у цілісну взаємозв'язану інформаційну інфраструктуру призвело до прийняття рішення щодо створення Єдиної інформаційної системи управління оборонними ресурсами (Defense Resources Management Information System DRMIS) [3].

Нагальною проблемою, на вирішення якої спрямовано створення DRMIS, $\epsilon$ необхідність забезпечення органів військового управління інформаційно-аналітичною складовою (інструментарієм) для підтримки прийняття рішень у сфері управління оборонними ресурсами.

Завдання створення DRMIS є складним, оскільки, по-перше, DRMIS має об'єднати IC, які створюються різними розробниками та використовують різні програмні платформи i системи управління базами даних, по-друге, більшість IC працюють у локальних мережах, що викликано тією обставиною, що в них циркулює інформація 3 обмеженим доступом. Це значно ускладнює обмін даними між IC для отримання актуальної та цілісної інформації для прийняття рішень.

Одним із шляхів розв'язання зазначених проблем $€$ вдосконалення функціональної взаємодії наявних i перспективних IC 
управління оборонними ресурсами на основі побудови інформаційної інфраструктури, що дасть змогу інтегрувати розрізнені IC у єдину систему DRMIS, в якій у структурованому вигляді консолідується інформація, забезпечується оперативний доступ до цієї інформації для аналізу і прийняття рішень.

Метою статті є визначення технологічних рішень щодо створення Єдиної інформаційної системи управління оборонними ресурсами на основі аналізу взаємодії функціональних процесів, підходів до створення інтеграційних рішень та сценаріїв їх застосування.

\section{Виклад основного матеріалу.} Відповідно до Стратегії розвитку інформаційного суспільства в Україні, інформачійна інфраструктура - це сукупність різноманітних інформаційних (автоматизованих) систем, інформаційних ресурсів, телекомунікаційних мереж і каналів передачі даних, засобів комунікації i управління інформаційними потоками, а також організаційно-технічних структур, механізмів, що забезпечують їх функціонування [4].

У рамках цієї Стратегії та Концепції розвитку електронного урядування в Україні [5] визначаються лише стратегічні напрями та концептуальні підходи до впровадження IT в державних органах управління за відсутності як конкретних показників, що треба досягти, так і практичних заходів з їх реалізації.

Отже, доречним продовженням документів, які формують державну політику щодо розвитку інформаційного суспільства, виступають такі документи, як програми та/або плани заходів з розвитку інформаційної інфраструктури із зазначенням переліку конкретних заходів, відповідальних, фінансування $\mathrm{i}$ чіткого розподілу повноважень. Також у межах цих документів визначаються показники для всіх елементів інформаційної інфраструктури, яких потрібно досягти під час іiї розвитку.

Таким документом для 3С України стала затверджена Міністром оборони України 12 травня 2018 року Концепція відомчих програм створення Єдиної автоматизованої системи управління Збройними Силами України, Єдиної інформаційної системи управління оборонними ресурсами та інформаційної інфраструктури на період до 2020 року (далі - Концепція).

у Концепції визначено, що найраціональнішим варіантом створення Єдиної інформаційної системи управління оборонними ресурсами та інформаційної інфраструктури $\epsilon$ підхід 3 використанням сервіс-орієнтованої інтеграційної платформи (закордонного або вітчизняного розробника) для розроблення нових інтегрованих програмно-технічних рішень (за неавтоматизованими функціональними напрямами) та забезпечення їх сумісності (інтероперабельності) 3 наявними інформаційними та автоматизованими системами.

Насамперед передбачається:

використати уніфіковані рішення на основі єдиної інтеграційної платформи; мінімізувати кількість розробників; передбачити можливість підготовки користувачів власними, навченими фахівцями; використати існуючі IC, на розроблення та впровадження яких витрачено значний фінансовий ресурс.

Найраціональнішими шляхами та способами реалізації зазначеного варіанта вважаються: формування та удосконалення нормативно-правової бази з питань створення, впровадження, експлуатації, супроводження Єдиної автоматизованої системи управління Збройними Силами України (САСУ ЗС України), Єдиної інформаційної системи управління оборонними ресурсами та інформаційної інфраструктури;

створення системи взаємопов'язаних організаційних структур, відповідальних за повний життєвий цикл системи;

удосконалення системи підготовки фахівців 3 питань застосування та експлуатації автоматизованих (інформаційних) систем військового призначення;

$$
\text { розроблення та }
$$

впровадження комплексів засобів автоматизації (програмно-технічних комплексів) автоматизованих систем різного функціонального призначення;

розроблення уніфікованих програмнотехнічних платформ i спеціального програмного забезпечення (СПЗ);

розвиток і модернізація через введення нових функціональних систем (сервісів), розширення функцій створених систем, підключення нових інформаційних ресурсів $\mathrm{i}$ розширення кола користувачів;

розвиток інформаційної інфраструктури в інтересах створення САСУ ЗС України та іiі складових;

формування єдиних правил, політик i стандартів технічної та інформаційної сумісності автоматизованих (інформаційних) 
систем та їх компонентів, зокрема врахування стандартів НАТО щодо побудови та розвитку комунікаційних та інформаційних систем.

Вирішення зазначених завдань потребує здійснення цілеспрямованих, скоординованих за термінами, обсягами ресурсного забезпечення заходів щодо приведення існуючої інформаційної інфраструктури до сучасних потреб. У більшості сучасних IC автоматизовані лише деякі функції, окремі частини функціональних процесів. Побудова інформаційної системи, яка функціонує у вигляді єдиної системи, що забезпечує прозоре управління функціональними процесами, гнучко адаптується під будь-які зміни - $є$ одним із пріоритетних завдань.

3 погляду обгрунтування технологічних рішень щодо побудови DRMIS та інформаційної інфраструктури, основоположні питання пов'язані 3 запровадженням комплексної інтеграції IC управління оборонними ресурсами на основі сучасних IT і стандартів провідних країнчленів НАТО, що забезпечить необхідний рівень оперативності, достовірності та повноти інформації, необхідної для прийняття управлінських рішень керівництвом МО України та ЗС України.

Основними процесами, що підлягають автоматизації у складі DRMIS, є підтримка процесів оборонного та мобілізаційного планування, матеріально-технічного, медичного та інших видів забезпечення, управління фінансово-економічною діяльністю, особовим складом, організаційною структурою, майном, закупівлями, іншими видами адміністративної діяльності. Створення DRMIS грунтується на переході від “кускової” автоматизації зазначених функціональних процесів до підходу, який характеризується інтеграцією інформаційних систем.

Завдання інтеграції IC виникає через те, що, по-перше, більшість IC автоматизують лише деякі функції і частини функціональних процесів, по-друге, існує великий обсяг даних, потрібний для прийняття рішень (фактично розподілений між різними IC управління оборонними ресурсами, а у перспективі й між системами бойового (оперативного) управління, по-третє, IC створюються різними розробниками, які використовують різні програмні платформи.

Процес інтеграції IC може розглядатися як забезпечення можливості обміну даними між окремо взятими IC, або як повна реструктуризація інформаційної інфраструктури для вирішення завдань управлінської діяльності.

Перший підхід не викликає особливих складнощів - відповідні технології відомі та легко можуть бути впроваджені. Інтеграція даних в IC розуміється як забезпечення єдиного уніфікованого інтерфейсу для доступу до деякої сукупності неоднорідних незалежних джерел даних [6]. Таким чином, інформаційні ресурси всієї сукупності інтегрованих джерел являють собою нове єдине джерело.

Система, що забезпечує такі можливості, називається системою інтеграиії даних. Суть цього підходу полягає в такому: окремі IC працюють незалежно одна від одної, кожна використовує свій набір даних. У разі необхідності здійснюється обмін даними між IC. Обмін даними проводиться між базами даних визначених IC на основі методів консолідації, федералізації, поширення даних або комбінації цих методів (табл. 1).

Підходи до інтеграції інформаційних систем

Таблиця 1

\begin{tabular}{|c|c|}
\hline ПІДХІД & ОПИС \\
\hline \multirow{4}{*}{ Інтеграція на рівні даних } & $\begin{array}{l}\text { Консолідація (інтеграція на фізичному рівні) - технології ETL (Extract- } \\
\text { Transform-Load) i ECM (Enterprise Content Management) - дані збираються } 3 \\
\text { декількох первинних IC й інтегруються в єдине постійне місце зберігання }\end{array}$ \\
\hline & $\begin{array}{l}\text { Федералізація (інтеграція на логічному рівні) - технологія EII (Enterprise } \\
\text { Information Integration) - забезпечує єдину віртуальну копію декількох первинних } \\
\text { джерел даних }\end{array}$ \\
\hline & $\begin{array}{l}\text { Поширення - технологія EDR (Enterprise Data Replication) - копіювання даних } 3 \\
\text { одного місця в інше. Цей підхід використовується для обміну даними у } \\
\text { реальному часі, що відбувається відповідно до певних подій }\end{array}$ \\
\hline & Гібридний підхід використовує кілька технологій \\
\hline $\begin{array}{l}\text { Інтеграція на } \\
\text { корпоративних } \\
\text { застосувань }\end{array}$ & $\begin{array}{l}\text { EAI (Enterprise Application Integration) - спільне використання виконуваного } \\
\text { коду, а не внутрішніх даних IC, що розбивається на компоненти, які } \\
\text { інтегруються за допомогою стандартизованих програмних інтерфейсів і СПЗ }\end{array}$ \\
\hline $\begin{array}{l}\text { Інтеграція за допомогою } \\
\text { Web-сервісів }\end{array}$ & $\begin{array}{l}\text { SOA (Service-oriented architecture) - заснований на забезпеченні стандартного } \\
\text { інтерфейсу доступу до програм та даних у вигляді Web-служб }\end{array}$ \\
\hline
\end{tabular}


Застосування другого підходу викликає низку проблем: як забезпечити сумісність між системами, взаємодію СПЗ та отримання єдиного інформаційного простору для підтримки наскрізних процесів управління. Розв'язання цих проблем полягає в створенні системи інтеграції корпоративного рівня Enterprise Application Integration (EAI) комбінації процесів, програмних засобів, стандартів i апаратури, завдяки якій здійснюється "безшовна" інтеграція двох або більше IC, що дає змогу їм функціонувати як єдина система $[6,7]$. Кожна IC надає сервіси, які $\epsilon$ інтерфейсами до певної функціональності. Взаємодія між IC проходить в межах визначеного функціонального процесу, на окремих кроках якого здійснюється виклик того чи іншого сервісу. Функціональність окремої IC може забезпечуватися за допомогою виклику сервісів, що надаються як цією IC, так і іншими системами. Таким чином, на одному кроці функціонального процесу можуть взаємодіяти декілька сервісів.

Застосування Web-технологій під час створення систем $\boldsymbol{E A I}$ дало змогу об'єднати сервіси в окремий рівень, який абстрагує функціональні процеси від технології доставки даних із різних джерел. Це призвело до появи, так званої, сервісно-орієнтованої архітектури - Service-Oriented Architecture $(\boldsymbol{S O A})$ Рівень сервісів дає змогу інкапсулювати функціональні можливості IC у компоненти, доступні для багаторазового використання іншими IC у різних сценаріях інтеграції даних. Наявність рівня сервісів дає змогу розгортати в єдиному середовищі функції інтеграції даних у вигляді сервісів та управляти їх наданням.

Існування різних інтеграційних підходів породжує задачу вибору оптимального рішення, яке, в свою чергу, зумовить можливості єдиної інформаційної системи (див. табл. 1).

Вибір одного 3 інтеграційних підходів визначає такі сценарії:

інтеграція кількох IC для тимчасового вирішення інтеграційних завдань;

застосування інтеграції 3 наміром перевести інформаційну інфраструктуру на якісно новий рівень розвитку.

Останні тенденції розвитку IT свідчать про поступове об'єднання інтеграційних підходів. Так, розробники корпоративних IC застосовують спеціалізовані інтеграчійні платформи для створення базису своїх рішень [7]. Це дає змогу автоматизувати унікальні функціональні процеси, оперативно реагувати на різні потреби.

Під час створення інтеграційної платформи виникає низка завдань, склад яких залежить від вимог до неї та застосованого підходу. До них, зокрема, належать:

розроблення архітектури інтеграційної платформи;

створення моделі інтеграції даних, що $\epsilon$ основою єдиного інтерфейсу;

розроблення методів відображення моделей даних i побудова відображень в інтегруючу модель для моделей, які підтримуються окремими джерелами даних; інтеграція метаданих, які використовуються в системі джерел даних; подолання неоднорідності джерел даних; розроблення механізмів семантичної інтеграції джерел даних.

За умови збільшення кількості зв'язків між IC, складно забезпечити своєчасну синхронізацію даних і гарантувати якість їх перенесення. Результатом $\epsilon$ рішення, яке масштабується і керується у недостатньому обсязі.

Розв'язання цієї проблеми полягає в тому, що IC підключаються через спеціальний логічний компонент, так звану шину обміну даними. IC посилає повідомлення в шину, яка доставляє повідомлення всім іншим IC через загальну інфраструктуру. Кожна IC взаємодіє тільки 3 шиною обміну даними, таким чином кожна IC має єдиний зв'язок. Така модель взаємодії лягла в основу створення сервісної шини обміну даними - Enterprise Service Bus $(\boldsymbol{E S B})$, яка забезпечує керовану взаємодію між окремими IC.

Шина обміну даними призначена для вирішення таких завдань:

реалізація наскрізних функціональних процесів;

обмін повідомленнями між IC;

синхронізація довідкової інформації між різними IC;

конвертація транспортних протоколів між IC;

конвертація форматів даних між ICджерелом і IC-приймачем;

організація єдиної точки доступу до послуг (сервісів);

управління подіями різних джерел.

Нині на ринку програмного забезпечення можна виділити дві групи пропозицій для побудови $\boldsymbol{E} \boldsymbol{S B}$. Ці групи відрізняються як за ціною, так і за функціональністю.

Перша група - комерційні продукти, що лідирують у дослідженнях аналітичних агентств: 
IBM 3 лінійкою продуктів WebSphere; Software AG 3 інтеграційною. платформою WebMethods; Oracle 3 лінійкою Fussion Middleware; Tibco 3 лінійкою Business Integration.

Друга група - безкоштовні продукти 3 відкритим кодом, що розробляються open-source спільнотами. Найвідоміші 3 них: Apache 3 продуктом ServiceMix; Sun Microsystems 3 продуктом Open ESB; Red Hat 3 продуктом JBossESB; Mule $з$ продуктом MuleESB.

Зазначені продукти далеко не $\epsilon$ вичерпними, але ілюструють загальні тенденції і підходи, які виникають під час створення систем на основі ESB. Усі вони потребують певного налаштування для створення архітектури, яка відповідає принципам SOA та унікальним вимогам конкретної єдиної системи. Для визначення раціонального варіанта побудови DRMIS та інформаційної інфраструктури на основі ESB використаємо методику аналізу оцінювання слабких i сильних сторін різних варіантів - SWOT (Strengths, Weaknesses, Opportunities, Threats, ), табл. 2.

SWOT-аналіз варіантів упровадження інтеграційної платформи

Таблиця 2

\begin{tabular}{|c|c|c|}
\hline Показники & Комерційне ПЗ & ПЗ із відкритим кодом \\
\hline $\begin{array}{l}\text { Переваги } \\
\text { (Strength) }\end{array}$ & $\begin{array}{l}\text { готові перевірені рішення реалізації функціональних } \\
\text { процесів на основі найкращих практик впровадження; } \\
\text { єдина технологія побудови системи, єдина платформа, } \\
\text { єдиний розробник; } \\
\text { відпрацьована технологія впровадження; } \\
\text { наявність на ринку праці фахівців з впровадження і } \\
\text { підтримки типових рішень; } \\
\text { короткі терміни впровадження завдяки готовим } \\
\text { рішенням; } \\
\text { висока якість продукту з використанням підходів та } \\
\text { технологій, що відповідають сучасним стандартам } \\
\text { кібербезпеки та захисту інформації; } \\
\text { стандартизовані процедури технічної підтримки та } \\
\text { повний пакет документації для подальшого розвитку } \\
\text { системи; } \\
\begin{array}{l}\text { швидке навчання спеціалістів за відпрацьованими } \\
\text { курсами та тренінгами }\end{array}\end{array}$ & $\begin{array}{l}\text { гнучкий вибір архітектури системи та } \\
\text { стандартів ії впровадження залежно від } \\
\text { iснуючого ІТ-ландшафту; } \\
\text { гнучкість у використанні методик і алгоритмів } \\
\text { для реалізації типових і нетипових } \\
\text { функціональних процесів; } \\
\text { більш широкий ринок команд програмістів для } \\
\text { реалізації нетипових рішень; } \\
\text { система може бути адаптована та впроваджена } \\
\text { різними компаніями згідно з вибором } \\
\text { замовника; } \\
\text { вартість володіння системою росте пропорційно } \\
\text { реалізації функціональності }\end{array}$ \\
\hline $\begin{array}{c}\text { Недоліки } \\
\text { (Weaknesses) }\end{array}$ & $\begin{array}{l}\text { залежність вартості програмного продукту та технічної } \\
\text { підтримки від умов виробника; } \\
\text { надто висока вартість володіння на початкових стадіях, } \\
\text { коли використовується не весь реалізований } \\
\text { функціонал системи; } \\
\text { подальша вартість володіння системою залежить від } \\
\text { політики виробника щодо підтримки рішення }\end{array}$ & $\begin{array}{l}\text { залежність якості програмного продукту від } \\
\text { кваліфікації системного архітектора; } \\
\text { необхідність витрати часу та ресурсів на } \\
\text { розроблення системної архітектури та ядра } \\
\text { системи; } \\
\text { відтермінування початку впровадження через } \\
\text { необхідність розроблення унікального ПЗ; } \\
\text { можлива істотна затримка реалізації проекту у } \\
\text { разі помилкового вибору системних рішень; } \\
\text { необхідність детальнішого документування } \\
\text { робіт; } \\
\text { нижча, ніж у стандартного, якість ПЗ за } \\
\text { кількістю помилок у стандартних } \\
\text { функціональних модулях; } \\
\text { вартість володіння під час використання } \\
\text { унікального Пзє найвищою }\end{array}$ \\
\hline $\begin{array}{c}\text { Можливості } \\
\text { (Opportunities) }\end{array}$ & 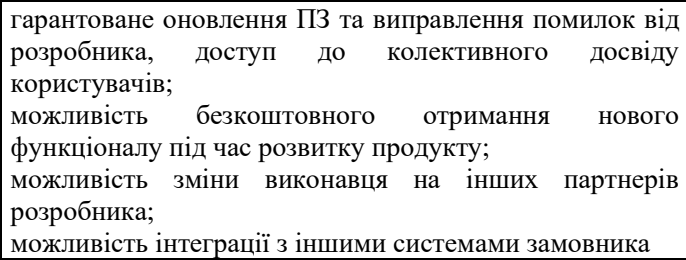 & $\begin{array}{l}\text { можливість впливу на технологічні аспекти } \\
\text { проекту розроблення ПЗ; } \\
\text { можливість глибоких змін у ядрі системи; } \\
\text { можливість модернізації системного та } \\
\begin{array}{l}\text { апаратного ландшафту; } \\
\text { відсутність залежності сукупної вартості } \\
\text { володіння від кількості користувачів }\end{array}\end{array}$ \\
\hline $\begin{array}{l}\text { Загрози } \\
\text { (Threats) }\end{array}$ & $\begin{array}{l}\text { складність та комплексний характер системи не дають } \\
\text { змоги однаково вдало її впровадити у різні підрозділи } \\
\text { великої організації } \\
\text { наявні типові рішення не повною мірою враховують } \\
\text { галузеву специфіку організації; } \\
\text { обмеженість глибини адаптації ПЗ для замовника } \\
\text { наявними архітектурою та стандартами ПЗ від } \\
\begin{array}{l}\text { виробника; } \\
\text { можлива необхідність реінжинірингу (адаптації) } \\
\text { функціональних процесів під можливості Пз }\end{array}\end{array}$ & $\begin{array}{l}\text { неможливість зміни розробника через } \\
\text { унікальність продукту; } \\
\text { можливі ризики неуспішного розроблення } \\
\text { та/або впровадження через складності інтеграції } \\
\text { багатьох бізнес-процесів великої організації }\end{array}$ \\
\hline
\end{tabular}

Висновки. Підхід на основі сервісної шини обміну даними ESB має широкі функціональні можливості організації взаємодії IC. Він дає змогу зберегти інвестиції в існуючі IC, інтегрувати їх у єдину інформаційну систему. У разі заміни успадкованих IC використання інструментів цього підходу дасть змогу зробити процес 
модернізації поступовим i непомітним для кінцевих користувачів. Основними напрямами створення DRMIS $€$ формування сучасної інформаційної інфраструктури, модернізація та захист інформаційно-телекомунікаційних мереж, забезпечення інтеграції сучасних та перспективних інформаційних систем управління оборонними ресурсами у єдину систему.

Напрями подальших досліджень. Відмінності розглянутих способів інтеграції IC потребують проведення детальнішого аналізу та оцінювання функціональних можливостей кожного 3 них, порівняння архітектури інтеграційних рішень i можливостей їх компонентів, вироблення методології, яка описує можливі варіанти вирішення інтеграційних завдань залежно від початкових умов. Вибір підходу та технологій, на яких він буде заснований, багато в чому визначить можливості та тенденції розвитку Єдиної інформаційної системи управління оборонними ресурсами.

\section{СПИСОК ВИКОРИСТАНОЇ ЛІТЕРАТУРИ}

1. Морозов А. О. Управління розробкою Єдиної АСУ збройних сил / А. О. Морозов, В. А. Косс // Наука і оборона. - 2006. - № 2. - С. 30-34. - Режим доступу: http://www.immsp.kiev.ua/perspages/ koss_va/publ/5_syst_proekt.pdf.

2. Артюх В. М. Современный этап разработки и строительства Единой автоматизированной системы управления Вооруженными Силами Украины /
В. М. Артюх, В. К. Медведев // Оборонный вестник. - 2012. - № 1. - С. 15-24. - Режим доступу: http://defpol.org.ua/site/files/OV_1_2012_rus.pdf.

3. Про рішення Ради національної безпеки і оборони України від 20 травня 2016 року “Про Стратегічний оборонний бюлетень України” [Електронний ресурс]: указ [видано Президентом України 06 червня 2016 р. №240/2016]. - Режим доступу: http://www.president.gov.ua/documents/ 240201620137.

4. Про схвалення Стратегії розвитку інформаційного суспільства в Україні [Електронний ресурс]: розпорядження [видано Кабінетом міністрів України 15 травня 2013 р. № 386-р 611.] - Режим доступу: http://www.president.gov.ua/documents/ 240201620137.

5. Про схвалення Концепції розвитку електронного урядування в Україні [Електронний ресурс]: розпорядження [видано Кабінетом міністрів України 20 вересня 2017 р. № 649-р 2017.] - Режим доступу: http://zakon.rada.gov.ua/ laws/show/649-2017-p.

6. Кірпічніков Ю. А. Аналіз світового досвіду застосування інтеграційних технологій у автоматизованих системах управління / Ю. А. Кірпічніков, М. К. Утюшев, М. А. Закалад та ін. // Збірник наукових праць ЦВСД НУОУ ім. Івана Черняховського. - 2016. - № 3 (58). - С. 131-135.

7. Кірпічніков Ю. А. Аналіз поняття інтеграційної платформи та методів інтеграції даних інформаційних систем управління оборонними ресурсами / Ю. А. Кірпічніков, О. В. Андрощук, М. В. Петрушен// Збірник наукових праць ЦВСД НУОУ ім. Івана Черняховського. - 2017. - № 2 (60). - C. $73-78$.

\section{Стаття надійшла до редакційної колегії 12.03.2019}

Кирпичников Ю. А., к.т.н.;

Адрощук О. В., к.психол.н.;

Головченко А. В.;

Петрушен Н. В.

Центр военно-стратегических исследований Национального университета обороны Украины имени Ивана Черняховского, Киев

Определение технологических решений по созданию Единой информационной системы управления оборонными ресурсами

Резюме. В Министерстве обороны Украины осуществляется создание Единой информационной системы управления оборонными ресурсами. Статья посвящена проблеме определения технологических решений по построению информационной инфраструктуры, которая является основой системы такого уровня.

Ключевые слова: управление оборонными ресурсами; информационная инфраструктура; система интеграции данных; интеграционная платформа; сервисная шина обмена данными.

Y. Kirpichnikov, PhD (Technical);

O. Androshchuk, PhD (Psychology);

O. Golovchenko;

N. Petrushen

Military Strategic Research Center of National Defence University of Ukraine named after Ivan Chernyhovskij, Kyiv

Definition of technological solutions to create a Unified Defense Resources Management Information System

Summary. In the Ministry of Defense of Ukraine, the creation of a Unified Defense Resources Management Information System is focused. The article is devoted to the problem of determining technological solutions for building information infrastructure, which is the basis of a system of this level.

Keywords: defense resource management; information infrastructure; data integration system; integration platform; enterprise service bus. 